\title{
Alienage Issues in the Merchant of Venice
}

\author{
Tatevik S. Karapetyan* \\ PhD Candidate, Post doctorate researcher, Foundation of Giorgio Cini Onlus (Venice), Head of the \\ Department of Humanitarian Subjects, Associate Professor, the University of Traditional Medicine, Armenia. \\ *Corresponding Authors: Tatevik S. Karapetyan, PhD Candidate, Post doctorate researcher, \\ Foundation of Giorgio Cini Onlus (Venice), Head of the Department of Humanitarian Subjects, Associate \\ Professor, the University of Traditional Medicine, Armenia.
}

\begin{abstract}
The Merchant of Venice is the most prominent work in terms of presenting foreign characters, different religions and groups in World Literature. Shylock is a tax evasion Jew who hates Antonio who lends money without interests. So, Antonio is an obstacle for Shylock, as Antonio makes Shylock lose in his trade. Shylock keeps an eye on Antonio's actions to catch a false step so that he "can catch him" "upon the hip" (1.3.42). The utterance "Cursed be my tribe, if I forgive him!" (1.3.47-48) shows the inhumanity in Shylock who tries to gain some power to take his revenge. One of the reasons for his revenge is that Antonio "hates" the sacred nation of the Jews. The aim of current article is to discuss such legal issues as alien, law of residents and foreigners in Venice during 16th century and make a comparative analysis on the basis of The Merchant of Venice.
\end{abstract}

Keywords: alien, alienage, reconquista, immigrant group, hostile, racial and cultural outsiders.

Acknowledgements: I respect and thank the Government of the Republic of Italy, for providing me an opportunity to do the project, work in Foundation of Giorgio Cini Onlus (Venice). I am extremely thankful to Professor E. Palandri for providing such a nice support and guidance.

\section{INTRODUCTION}

Alienation and accordingly the notion of alien are one of the most widely-confronted phenomena not only in philosophy, psychology, sociology and politics, but also in literature of various genres. Almost every individual in society inevitably experiences some form of alienation in their everyday lives. Shylock, in William Shakespeare's The Merchant of Venice, stands alone despite his economic situation and legal bond. Here religious prejudice, economic opportunities and ethnicity form the basis of alien, in a way that different characters consider Shylock not only a threat to common patterns in the commercial system and capital profit, but also a physical threat to the life of Antonio. The Venetians talk about Shylock as a cruel individual without mercy. Jessica, Shylock's Christian daughter, also experiences being considered as an alien for society, as she is viewed in the same way as her father. Here residents of Venice considered Shylock and other strangers a threat to their values, reflecting some type of alien factors, such as economic and political crisis and increased immigration, that were common in the Shakespearean period. The mental approach to this social phenomenon can be explained using sociological theories. Although some literature reviews will be discussed in line with the notion that The Merchant of Venice is written in the format as Shakespeare was in Venice. Accordingly, the main objective of this paper is to identify evidence of alien, make a comparative analysis about interpretation of alienation in Venice in $16^{\text {th }}$ century.

\section{LITERATURE REVIEW}

Spain's defeat by England in 1588, and the increase in Elizabeth I's power in Europe, had earlier prompted the efforts to discover new lands in America, and developed trade and political ties with the Ottoman Empire and African countries; a form of nationalism started to evolve among British settlers (Suratgar 1994: 235). After Elizabeth I came to power, immigrants from different backgrounds, such as Jews, Muslims and even gypsies increasingly settled in Britain. Deportation and abuse of Jews and Muslims from Spain was also prominent at that time. During this acquisition of Spain, the recapturing of Granada from Muslims and initiation of 'Reconquista' was intensified. Reconquista was an 
initiative aimed at harmonizing different nationals together with the majority Christian community; this also gave rise to racism (Loomba 2002: 114).

This kind of opinion was prevalent in most European countries such as Spain, Italy and Portugal. However, in England, Muslim and Jewish immigrants, as well as settlers from North Africa experienced better treatment because of the power of Protestants and their inclination to develop the sovereignty of Britain. British public opinion about different nations was formed by reading different travel accounts, books and historical-religious background. However, the fear of being attacked by strangers and losing its newly obtained power, fostered the bloody struggles and abuse of immigrants that resulted from incorrect prejudice and economic competition between England and foreigners (Goose 2005: 110-111). Therefore, such small immigrant groups lived in isolation and were considered the other or aliens (Shapiro 1996: 6).

Shapiro argues that intensified political riots, unemployment and religious prejudices in England, affected the lives of immigrants under colonial powers who considered them as threats against their sovereignty. For this reason, immigrants were deprived from their rights as citizens. As prejudices against immigrants in England grew, the promise of new life for Jews was broken and Queen Elizabeth 1 ordered the deportation of Jewish people in 1593, declaring that no Jew could enter England. The order was maintained till 1656. Any Jew entering England in the period between Late Sixteenth to early Seventeenth century was referred to as an alien (Shapiro 1996: 203). Experiences of commerce and travel accounts by English explorers, including Tomas Coryate (c. 1577-1617), on the other hand, brought the European community an exaggerated stereotype of Jews.

Jews who were deported from European countries migrated to Africa and Asia, such that, more than 250,000 Jews were living in the Ottoman Empire, where they were not only successful merchants, but also occupied governmental authority. They were noncompliant competitors of English merchants who were also trying to stabilize their position in the region. Many English merchants believed that making these merchants Christian would help them achieve their goal. Many Jews of Venice were in fact the merchants of the Ottoman Empire (Shapiro 1996: 177). This attitude is seen at the time of Christianizing Shylock in The Merchant of Venice, in Act 4, scene 1.

The stereotypes formed in the Middle Ages and early Renaissance were in the essence that Loomba refers to stereotypes given to the Jews in her book: "Jews had hooky nose, and were accused of killing children in religious ceremonies, poisoning Christians, circumcising Christians and exploiting Christians economically through usury. Such prejudices manifested in different times and places in various forms" (Loomba 2002: 114). Cutting one pound of Antonio's flesh in The Merchant of Venice may be a reflection of the rumour about Jews regarding circumcision and sacrifice. Shapiro believed that for the closed Jewish community in Elizabethan England, the idea formed among the public that the ritual could be part of 'human sacrifice', while in the early Renaissance, discouraging concepts of the ritual was propagated in Europe, indicating the religious, racial and sexual anxiety that intensified in the Elizabethan period (Shapiro 1996: 143). It has been stated that Shakespeare is not racist and is only explaining the events of tension and prejudices during the era of Elizabeth 1 (Shapiro 1996: 203).

Foreigners from different nations entering London in Shakespeare's time, experienced various reactions from the English people and Elizabeth I, and this is reflected in the Bard's plays (Binda 2010: 58). Such reactions resulted in negative presumptions towards different nations based on reasons like fear of losing historical background, or loss of economic and social opportunities, thereby leading to protests against foreign immigrants. Shakespeare captures all the real events that occurred at that time, with various roots of alienage, foreigner interpretations in The Merchant of Venice.

Goose believed that the creation of characters such as Shylock, Othello, Caliban, Cleopatra and Aaron was a reflection of Britain's fear of foreigners. The common aspect of all main characters of these plays is that they are all foreigners, who are different from Europeans, in terms of ethnicity. Although the word "Xenophobia" was not discussed in English Renascence as openly as in modern times, this phenomenon existed in Shakespeare's works and it was mentioned in the 17th century (Goose 2005: 110-111). According to Akokpari, xenophobia is an act of fear of strangers. It is based on racial, cultural and religious prejudices that can lead to preventive behaviors, fanaticism and removing "The Other".

Despite the similarities between xenophobia and racism, they are still considered as two different phenomena. Racism is usually classified on the basis of stereotypical prejudices towards one's race or 
physical features such as skin colour and facial expressions. However, xenophobia is based on behaviors in which "The Other" is an individual different from the community, and originates from another country (Akokpari 2000: 72-92).

Critics who defend Shylock, whether via a sympathetic reading of his role in the play, or out of a respect for the terrible history of Jewish persecution, tend to darken the conditions provided for the Jews in Venice and to ignore the real disproportion between the largely verbal violence offered to Shylock by some members of the Christian majority, and the intent to commit judicial murder that comes within Shylock's grasp, and which he seems fully prepared to pursue. Factors of xenophobia are seen in five works of Shakespeare; Othello, The Tempest, Titus Andronicus, Antony and Cleopatra and The Merchant of Venice. Among these dramas, there are aliens or strangers from different religious minorities, ethnicities or skin colour, which are considered as threats against social or political situation or even as danger for the survival of the majority (in-group). Fear of immigrants and stranger's power (out-group) were prominent in the Shakespearean period (Alizadeh, Hashim, Amini, Mohtadi 2018; 5).

What refers to the Venetian government, it acknowledged the presence of foreigners by legislation that sought to control them. To give one significant example, in 1408 it forbade Jews from holding religious services in premises rented from Christian landlords, subject to a year in jail and a fine of 1000 lire for both the Christian landlord and the Jewish tenant, while all other Jews present at the services were to spend six months in jail and pay 300 lire. Subsequently, however, when in 1464 the Jews requested an alleviation of this measure, the collegio granted their wishes.

Pointing out that Pope Pius II (1458-64) had allowed Jews to practice their religion and had threatened with excommunication anyone who forbade them from doing so, it established that henceforth for the honor of God they could freely recite Psalms and praise God according to their laws in the premises that they rented, as long as not more than ten persons (the minimum quorum prescribed by Jewish law for the recitation of certain prayers and the public reading of the Pentateuch) participated. No traces have been found of any organized Jewish community or scuole, but it is reasonable to assume that some kind of embryonic association or at least ad hoc consultation must have existed (Ravid 1987: 169-202).

Many Venetians, especially Catholic preachers, were greatly bothered by the new phenomenon of Jews living spread throughout the city. Consequently, in 1516, the senate required all Jews to live together, segregated and enclosed on the island in Cannaregio already then known as the Ghetto nuovo (the new Ghetto) because of its association with the municipal copper foundry previously located across the canal, "il ghetto" or "getto" from gettare in the sense of pouring or casting metal, whose area came to be known as the Ghetto Vecchio (the old Ghetto) (Concina 1991: 1149; Ravid 2001, 7-10).

Only a person outside her own state can be qualified as a Convention refugee (Hathaway, 2014: 23). The alienage requirement of the definition is limiting status to an at-risk person who is "outside" her own country ("Refugee Convention", Art. 1(A)(2)).

By alienation is meant a mode of experience in which the person experiences himself as an alien. $\mathrm{He}$ has become, one might say, estranged from himself. He does not experience himself as the center of his world, as the creator of his own acts - but his acts and their - consequences have become his masters, whom he obeys, or whom he may even worship. The alienated person is out of touch with himself as he is out of touch with any other person. He, like the others, is experienced as things are experienced: with the senses and with common sense, but at the same time without being related to oneself and to the world outside productively (Fromm 1990:120).

In 1443 the Venetian Senate, taking note of the fact that schools of singing, music and dance had been opened by Jews for a presumably high-ranking Christian clientele, opposed, imposing fines and six months in prison for those who were surprised to undertake such activities ( Jacoby:170).

In the past it was taken for granted that Jews had been present in Venice and active in the commerce of the city as early as the twelfth century (Davis, Ravid 2001:3).

Yet although the Venetian government tolerated the presence of individual Jews in Venice it initially did not permit the open practice of their religion. Legislation of 1408 and 1426 claiming the Jews were establishing synagogues and holding services in quarters rented from Christians, with great 
offense to the Christian faith, condemned both such Jewish tenants and their Christian landlords to a year in jail and a fine of one thousand lire, while all other Jews attending the service were given six months in jail and a fine of three hundred lire.

The government was also still concerned about sexual contact between Jews and Christians, forbidding sexual relations between Jewish men and Christian women in 1424 and setting penalties according to the status of the Christian women (Davis, Ravid 2001:15).

The requirements to remain in the ghetto at night and to wear special distinguishing head-covering were often reiterated together in government legislation and administrative rulings, a particular reflection of the constant concern that Christian women might have sexual relations with unidentified Jews at night (Davis, Ravid 2001:21).

Ermanno Orlando states that Venice had, at the end of the Middle Ages, a population of approx 120,000 inhabitants, more than a third of whom were foreigners, of ancient or more recent immigration. In particular, the city included communities consisting of Dalmatians and Slavs, Germans, Albanians, Greeks, Armenians, Jews, Turks, Muslims and slaves: at the end of the fifteenth century, the estimates so far attempted have quantified the Germans and Albanians permanently resident in approximately 4,000 Venice; 5,000 Greeks; well over 5,000 Slavic Dalmatians. To these must be added the thousand and more Jews registered at the beginning of the sixteenth century; the very numerous, though fluid and submerged, team of slaves (in 1563 there were about 13,000 servants serving only the homes of eminent families including slaves, and servants in wages); in addition, of course, to the thousands of Italian speakers who immigrated from the nearby mainland or from other parts of the peninsula, especially from Lombardy, Florence and Lucca (Plebani 2016:17). Immigration was structurally connected to the needs of society; the city expressed an uninterrupted demand for manpower of import, both qualified and low-qualified, in particular of adaptable and flexible workers, to be used in the hardest and most demanding (and less paid) production activities, such as shipbuilding, the sea industry or the textile sector (Plebani 2016:18).

"Enemy," too, is an overgrown concept in the history of moneylending, one whose taproot lies in God's commandment that Israelites could lend at interest to strangers but not to their brothers. Though this commandment may originally have cut only between families, the requirement of brother hood came over time to be read as a collective metaphor for community. The Israelite could charge interest only to the non-Israelite, the Jew only to the non-Jew, and the Christian, called to universal brotherhood in the Gospels, could take interest from no one. As always, Saint Thomas Aquinas summarized well the Catholic exegetical consensus: "The Jews were forbidden to take usury from their brethren; i.e., from other Jews. By this we are given to understand that to take usury from any man is evil simply, because we ought to treat every man as our neighbor and brother, especially in the state of the Gospel, where to all are called (Nirenberg 2007:573-605).

To retain Jewish moneylenders as well as to attract Jewish merchants to Venice, it was necessary not only to enable them to survive physically and economically but also to assure them that they could practice their religion freely. Commencing in 1528, the charters of the tedeschi Jews established the basic principle that they could live according to their rites and customs, and conferred upon them many specific derivative rights.

\section{METHODS}

This study is a descriptive qualitative one, for it will describe and critically analyze the character of Shylock as an alien. Various theories of critical discourse analysis will be applied to reveal the social and verbal interaction between Jews and Christians in the play. One of these theories is the Social Psychology which is concerned with the relationship between language and power. It is a theory for Critical Discourse Analysis (CDA) is a special approach in discourse analysis which focuses on the discursive conditions, components and consequences of power. CDA is an application theory concerned with common social problems which highlight the practice of those in power, such as the Christians in Shakespeare's "The Merchant of Venice"; it reveals the ideology of the Christians who are interacting with the Jews in the play. Theories of in-group, out-group ${ }^{1}$ dynamics and Integrated

\footnotetext{
${ }^{1}$ In-group is a group of people who have common interests and activities, and do not allow members of other groups to enter their group as a means of protecting their territory. Out-group is a group of people who are
} 
Threat Theory $(\text { ITT })^{2}$ will be taken into consideration, when discussing the notion of alien and resident. The culture-historical method will be in line with this article as parallels will be between Venetian laws and their treatment towards Jews in 15-16th centuries.

\section{FINDINGS}

On the basis of discussion the findings are as follows; Shakespeare had clear knowledge of Venice as a social and economical state for writing The Merchant of Venice; he was aware of geographical segregation of the Jews and even described everything so impressively that one has the feeling that Shakespeare might have visited Venice. The other important fact is that he had decent knowledge of the Venetian legal system on behalf of the accessibility to many books and stories about very famous city. Thus the current article will be discussed in line with the existing venetian attitude towards foreigners, especially towards Jews.

\section{DISCUSSION}

As seen in the historic events, Venice was full of foreigners and accordingly there were some laws concerning the rights and obligations and specifically there were strict laws for Jews.

Since there could be no flesh without blood, in recognizing the right to take flesh, the Jew legally would have had all incidental powers necessary to the full enjoyment of the affirmative legal right and could draw the blood, as a necessary incident of the right to take the flesh, for without it, his right could not be exercised. It was axiomatic, at common law, that where one had a legal right, he had all the remedies necessary to a full enjoyment of that right, for otherwise the right itself would be without avail.

Portia leads Shylock almost to the point of Antonio's death, with her assurance that his suit is legally unassailable, and then with her famous injunction to pause - 'Tarry a little' - produces a devastating dramatic reversal, which sets the action spinning off in a completely opposite direction. The law still gives Shylock the right to exact his penalty: but other statutes render the exaction of the penalty a criminal offence. These laws, unlike the law protecting the cosmopolitan freedom of commercial exchange, are designed to protect the Venetian citizen against the hostile actions of racial and cultural outsiders. (White, 2002:131-132)

Christian identity is distinguished by authority, especially in the court scene in the play. It is known that Christians have power over Jews in the play and in real life during this period which leads to destruction at the end of the play to a Jew merchant called Shylock. As an illustration, Shylock tries to defeat the Christian merchant in the court scene, but unexpectedly, he is defeated.

Portia then declares that Shylock must...

\section{cut this flesh from off his breast}

The law allows it, and the court awards it. (4 1 299-300)

Portia is not correct however, when she states that Shylock must not take any blood;

This bond doth give thee here no jot of blood.

The words expressly are 'a pound of flesh'.

Take then thy bond Take thou thy pound of flesh.

But in the cutting of it, if thou dost shed

One drop of Christian blood.

Here it is very important to stress that Portia discriminates between Christian and Jew in terms of giving more importance to Christian blood, and accordingly with these words she differentiates

separated from their own group, and usually experience rage and dislike as a group of people who do not belong to a certain community, especially when they are humiliated because of their differences.

${ }^{2}$ Integrated Threat Theory (ITT) which was proposed by Walter S. Stephan \& Cookie White Stephan (2000), highlights the conditions and situations that results in the formation of prejudice, as well as the creation of threat and fear in-group behaviour. Such threats are there at any time, challenging the behaviour and beliefs of the ingroup (people of Venice) and making them perceive the out-group (Shylock) as a threat to the security of their group. 
between residents and foreigners, even though in real life it does not matter the nationality of a Christian, e.g. Greek, Armenian, German, etc.;

$$
\text { thy lands and goods }
$$

Are by the laws of Venice confiscate

Unto the state of Venice. (4. 1 302-09)

With these lines we also notice diversity of law between foreigners and residents of Venice. Shylock believes that mercy is as powerful as the consequence of a judgment at law;

The pound of flesh which I demand of him

Is dearly bought: 'tis mine, and I will have it.

If you deny me, fie upon your law!

There is no force in the decrees of Venice.

And accordingly with these lines we can state that Shylocks is suspicious towards the laws of Venice and their implementation in terms of a foreigner;

I stand for judgment.

Answer: shall I have it

because the law allows for the fact

that if one is entitled to something,

then one is entitled to whatever comes with that item.

In response to this legal error of Portia's,

The law still gives Shylock the right to exact his penalty: but other statutes render the exaction of the penalty a criminal offence. These laws, unlike the law protecting the cosmopolitan freedom of commercial exchange, are designed to protect the Venetian citizen against the hostile actions of racial and cultural outsiders:

Take then thy bond, take thou thy pound of flesh,

But in the cutting it, if thou dost shed

One drop of Christian blood, thy lands and goods

Are, by the laws of Venice confiscate

Unto the state of Venice. (4.1.304-8)

The subsequent directive for cuting off no more than 'a just pound' seems to be a part of the same law which protects Christian flesh against the non-Christian enemy. Portia invokes a law designed explicitly to treat them unequally in order to subvert the law that treats all men equally. The Jew would not by the same law be protected against the Christian, if the situation were reverse for a while. Finally, Portia reveals her bottom-line defense of Antonio, which is a conspiracy law targeted directly at the outsider:

It is enacted in the laws of Venice,

If it be proved against an alien

That by direct or indirect attempts

He seeks the life of any citizen,

The party 'gainst the which he doth contrive

Shall seize one half his goods, the other half

Comes to the privy coffer of the state,

And the offender's life lies in the mercy

Of the duke only, 'gainst all other voice. 
In which predicament I say, thou stand'st;

For it appears by manifest proceeding

That indirectly, and directly too,

Thou hast contrived against the very life

Of the defendant; and thou hast incurred

The danger formerly by me rehearsed. (4.1.344-57)

The 'trial' thus begins with a deadlock of competing economic interests, in which there is rational appeal beyond the validity of contract, as I have discussed on this in my article "Legal Interpretations of Shylock's Bond" where I stated that according to the archival materials such kind of bonds existed in Venetian law and they were considered valid. The protection afforded to contract by Venetian law binds the judicial authorities in a helpless subjection to the most literal legalism. Shylock's position as an alien is acknowledged but it is not permitted to influence his rights as a suitor. The Dodge appeals to Shylock on the basis of a universal morality, where the dominant values are mercy and forgiveness, and offers Shylock the opportunity of incorporation into a harmonized political economy where Jews would rationally forfeit their legal rights in the interests of the public good, and into a Christian ethical world of reciprocal forgiveness and mutual sympathy. Portia, openly showing the diversity between a Christian and a Jew, proceeds to use the power of Christian against him. Underlying the operational multi-culturalism of that cosmopolitan Venetian law, which Shylock believed would facilitate the judicial murder of Antonio, lies a legal structure designed to protect Christian Venice against aliens. It is within the harsh scope of this inequitable justice that Shylock has placed himself.

Shylock believed that Jews, who have two eyes and hands like Christians, also have the same feeling, so they have the right to take revenge. Shylock portrays the culmination of fear and alien against Jews and talks about discrimination in Christian community against him:

Shylock: you repeatedly called me pagan and brutal dog

and spited on my Jewish clothing (Shakespeare 1989: 410).

Here confrontation with the minority Jewish community is manifested by showing fear from negative stereotypes about the other (Shylock, the Jew). Shylock is defined by audiences as a vengeful, greedy, cunning, and cruel person, with Christian characters in The Merchant of Venice referring to him as the devil, fiend, dog, and wolf. They always called him Jewish in most dialogues and seldom used his name, Shylock.

Antonio: Mark you this, Bassanio,

The devil can cite Scripture for his purpose.

An evil soul producing holy witness is like a villain with a smiling cheek,

A goodly apple rotten at the heart:

$\mathrm{O}$, what a goodly outside falsehood hath!

Act IV Scene I

Economy also plays a great role in terms of alien as Shylock states; "I hate him for he is a Christian, But more for that in low simplicity. He lends out money gratis and brings down.

The rate of usance here with us in Venice".

Act I Scene III

Then, at the end, with the victory of Portia in the court, Antonio asks Shylock to convert to Christianity and that his wealth to be transferred to the newly baptized Jessica and her husband, Lorenzo, which indicates some type of monarchy of the Christian governing power over Judaism in the Shakespearean period and the destruction of any threat from strangers.

Portia: Wait, the Jews, the Law has another claim against you.

According to Venice law, if a stranger may directly or indirectly plot to kill a citizen,

half of his assets should be attached by one who had been subjected

under such plot and the other half is given to the treasury.

Act I Scene III 
In fact, Shylock is considered to be a threat against the economic and physical security of Antonio and the culmination of the play lies on this last part as the only better solution for Shylock is to convert to Christianity and this accordingly can solve many legal issues for Shylock.

\section{CONClusion}

As discussed above an alien experiences a sense of intergroup anxiety, which is a feeling of being detached from the in-group (native). Like Shylock tries to have his bond which is a form of interpretation of self-defense, as he wants to have legally what belongs to him and accordingly to reestablish justice. The Venetian law recognized a Jew as an 'alien' and Portia took advantage of the law to defeat Shylock giving him the opportunity to have his bond on the one hand, but on the other hand she brought an argument; firstly Shylock must cut only a pound of flash and if he cuts ha can kill a resident in case of which Shylock will be judged according to the criminal law of Venice. For this last part about criminal procedure further analysis will be done on the validity of the trial seen that shifts from civil procedure into criminal. But what is important in the whole play and specifically in the trial seen the alien (Shylock) is not legally protected in terms of taking what he has according to the bond, meanwhile "The affairs of Venice are governed with laws", which was the proud statement of the Republic, which thus distinguished itself from other forms of government (Sanuto, iii, 665).

\section{REFERENCES}

[1] Alizadeh F., Hashim M., Amini R., Mohtadi F., "Xenophobia in Shakespeare's The Merchant of Venice", SARJANA Vol. 33, No. 1, June 2018, pp. 11-21.

[2] Akokpari, John K. 2000. Globalisation and Migration. African Sociological Review, 4 (2), 72-92.

[3] Analysis of the rationale for the alienage requirement in J. C. Hathaway, The Law of Refugee Status (1991) ("Refugee Status") was cited by the High Court of Australia in Re Minister for Immigration and Multicultural Affairs; Ex parte Te, (2002) 212 CLR 162 (Aus. HC, Nov. 7, 2002), at 174 n. 54, per Gleeson C.J.; and was described by the English High Court of Justice as "plainly very persuasive": European Roma Rights Centre v. Immigration Officer at Prague Airport, [2002] EWHC 1989 (Eng. HC, Oct. 8, 2002), at [44]. The same passages were approved by the English Court of Appeal, which found the analysis to be "supported also by the authorities, domestic and foreign": R (European Roma Rights Centre) v. Immigration Officer at Prague Airport, [2004] QB 811 (Eng. CA, May 20, 2003), at 825 [38], per Simon Brown L.J.

[4] Binda, Hilary J. 2010. Shakespeare and Tolerance (Cambridge UP). The Journal of Early Modern Studies, 41 (3), 625-27.

[5] Bizman, Aharon \& Yinon, Yoel. 2001. Intergroup and Interpersonal Threats as Determinants of Prejudice: The Moderating Role of In-Group Identification. Basic and Applied Social Psychology, 23(3), 191-196.

[6] Concina E., "Parva Jerusalem," in E. Concina, V. Camerino, and d. Calabi, La città degli Ebrei: Il ghetto di Venezia: Archittetura e urbanistica (Venice, 1991), p. 1149; for a brief english summary.

[7] Convention relating to the Status of Refugees, adopted Jul. 28, 1951, entered into force Apr. 22, 1954, 189 UNTS 137 ("Refugee Convention" or "Convention"), at Art. 1(A)(2). A claimant with a nationality must be outside her country of nationality, while a claimant who is stateless must be outside her country of former habitual residence. The specific country or countries of reference are analyzed in detail infra, at Ch. 1.3 .

[8] Davis, Robert C. Ravid, Benjamin C. I.The Jews of Early Modern Venice [Publ.]. - Baltimore, Md. (2001).

[9] Fromm E., The Sane Society, (1990), Holt Paperbacks, ISBN 0-8050-1402-0.

[10] Goose, Nigel. 2005. Immigrants in Tudor and Early Stuart England. United Kingdom: Sussex Academic Press Eastbourne.

[11] Loomba, Ania. 2002. Shakespeare, Race, and Colonialism, P.H.S. Wells, Editor. New York: Oxford University Press.

[12] Nirenberg D., "The Politics of Love and Its Enemies," Critical Inquiry (2007):573-605.

[13] Plebani T., Stranieri, barbari, migranti: il racconto della storia per comprendere il present, Venezia, Biblioteca Nazionale Marciana, 2016, testi di Claudio Azzara, Ermanno Orlando, Lucia Nadin, Reinhold C. Mueller, Giuseppina Minchella, Vera Costantini, Andrea Zannini, Mario Infelise, Piero Brunello, Piero Lando.

[14] Jacoby, D., op. cit., p. 170, nota 30; problematico, tuttavia, appare il fatto che gli ebrei tenessero simili scuole, se è vero che potevano recarsi a $\mathrm{V}$. solo ogni quattro mesi.

[15] Ravid B., "The Legal status of the Jews of Venice to 1509," Proceedings of the American Academy for Jewish Research 54 (1987), 169-202. 
[16] Sanuto M., Cronachetta (Venice, 1880) 200-201. Girolamo Priuli also referred to this custom in his Diarii under the date 28 May, I5II (ms. in B.C.V., Provenienze diverse, P.D. 2.52-C, libro $6^{\circ}$, 206v seq.). In the capitularies of this office, preserved in A.S.V., there is no explicit mention of this: on the other hand, the principle of 2 March, 1318, which is mentioned in the text, is recorded there. On 21 Sept., 1474 a law of the Great Council, designed to put a limit to the excessive number of pardons conceded to the Cinque alia Pace, 'la qual cosa', it noted, 'da materia che senza timor de pena ogni uno ardisce disnudar arme et ferire cum exfusion di sangue', ordered that they could 'far grazia solo del quarto delle condanne pecuniarie' (Libro d'oro, pt. viii, £ 187).

[17] Shakespeare, William. 1989. The Complete Works of William Shakespeare. New York: Barnes \& Noble.

[18] Shapiro, James. 1996. Introduction. In: Shakespeare and the Jews. New York: Columbia University Press.

[19] Suratgar, Lutf A. 1994. History of English Literature (from the Sixtheenth Century to the Eighteenth Century). Tehran: University of Tehran Press.

[20] Watt, Home A.; Holzknecht, Karl J. \& Ross, Raymond. 1969. Outlines of Shakespeare's Plays: Synopses, Background Material, Genealogical Charts. New York: Barnes \& Noble.

[21] White, E. J. Commentaries on the Law in Shakespeare", University Press of the Pacific (December 23, 2002), ISBN-10: 1410203514, p. 584.

\section{AUTHOR'S BIOGRAPHY}

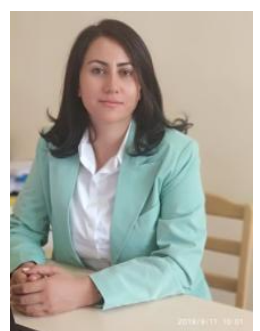

Dr. Tatevik S. Karapetyan, is a specialist in Comparative Literature. The focus of her research work at the Yerevan State University was centered round the European languages and Foreign Literature. During master's years she wrote thesis on the "New poetical movements in English and Anglo-American Literature in 20th century", after which she completed her $\mathrm{PhD}$ in philology namely 20th century Anglo-American drama in 2014 with the following doctoral thesis "Social and individual conflicts in the plays of Eugene O'Neill'.

She has been appointed as a literature expert for the scientific council of foreign and comparative literature in the Institute of Literature after M. Abeghyan of NAS of RA and gives scientific reviews for PhD thesis. Currently, she works as an expert at The National Center for Professional Education Quality Assurance Foundation (ANQA). She is also a Postdoc Researcher at the Branca Center in Fondazione Giorgio Cini and her main research activities are concerned with law and literature, economy and literature, social relations and literature.

Citation: Tatevik S. Karapetyan. "Alienage Issues in the Merchant of Venice" International Journal on Studies in English Language and Literature (IJSELL), vol 8, no. 7, 2020, pp. 01-09. doi: http://dx.doi.org/10.20431/2347-3134.0807001.

Copyright: (C) 2020 Authors. This is an open-access article distributed under the terms of the Creative Commons Attribution License, which permits unrestricted use, distribution, and reproduction in any medium, provided the original author and source are credited. 